\title{
I. ROZPRAWY
}

\author{
GRZEGORZ BIAŁUŃSKI (Olsztyn)
}

\section{Zemsta matką sprawiedliwości. Wergeld (główszczyzna) w Prusach Krzyżackich i Prusach Książęcych}

W świecie cywilizacji tradycyjnej (barbarzyńskiej) wymiar sprawiedliwości był realizowany w drodze samopomocy, tzw. wróżdy (legalnej zemsty rodowej, germ. faida). Zemsta musiała mieć charakter jawny i stanowiła wręcz obowiązek wszystkich współrodowców, oczywiście spośród ludzi wolnych. Legalność wróżdy wypływała również z jej sakralnego charakteru (stąd „święty” lub „honorowy obowiązek”). Celem wróżdy było zatem także przebłaganie bóstw poprzez złożenie ofiary z przestępcy, inaczej na ród lub wspólnotę mogły spaść ciężkie klęski żywiołowe bądź nieurodzaj. Często, do czasu wykonania zemsty, zwłoki czekały na pogrzebanie (,„zwłoki wołały o pomstę"). Można było zemścić się nie tylko na zabójcy, ale na każdym innym członku rodu. Na ogół starano się mścić na najbardziej znaczących członkach rodu, niekoniecznie na zabójcy, wtedy kara była bardziej dotkliwa, ale też dokonane zadośćuczynienie bardziej godne, a ofiara złożona bóstwom bardziej miła ${ }^{1}$.

Ubocznym efektem wróżdy były krwawe i wyniszczające wojny wewnętrzne, stąd z czasem wraz ze wzmocnieniem władzy zwierzchniej starano się ją wyrugować, a przynajmniej zastąpić zapłatą prywatnej kary, tzw. opłatą kompozycyjną, czyli główszczyzną (w świecie germańskim zwaną

${ }^{1}$ Z literatury ogólnej zob. P. Frauenstädt, Blutrache und Todtschlagsühne im deutschen Mittelalter. Studien zur Deutschen Kultur- und Rechtsgeschichte, Leipzig 1881; J. Kurczewski, Prawo prymitywne: zjawiska prawne $w$ społeczeństwach przedpaństwowych, Warszawa 1973, zwłaszcza s. 8-27, 94-95, 177-181, 216-220, 241-243, 263-264, 282-286; S. Ciszewski, Wróżda i pojednanie, Warszawa 1900; M. Bloch, Spoteczeństwo feudalne, Warszawa 2002, s. 147-152; K. Modzelewski, Barbarzyńska Europa, Warszawa 2004, s. 119-158; idem, Zemsta, okup i podmiot moralny w prawach barbarzyńskich, [w:] Aetas media, aetas moderna. Studia ofiarowane prof. H. Samsonowiczowi, red. H. Manikowska, A. Bartoszewicz, W. Fałkowski, Warszawa 2000, s. 273-285. 
wergeldem) $)^{2}$. Główszczyzna była wypłacana w naturze (u Germanów już w I w n.e., za „określoną liczbę trzody i bydła”3), a później w pieniądzu. Przyjęcie główszczyzny (opłaty za „głowę”, poena capitis) kończyło spór, wyrównywało stratę po zabójstwie (choć zwyczajowo to było trudne, stąd m.in. przysłowie „nie godzi się nosić worka pieniędzy za głowę zabitego"4), wówczas ewentualna zemsta była już nielegalna i wymagała od współrodowców kolejnej wróżdy, ewentualnie pojednania w postaci zgody na główszczyznę (zwykle w podwójnej wysokości). Spłata główszczyzny była obowiązkiem wszystkich współrodowców, nie tylko sprawcy zabójstwa. W podziale główszczyzny partycypował również cały ród, odpowiednio do stopnia pokrewieństwa (uszeregowanych według prawa bliższości). Wróżda pozostawała nadal legalna, gdy zabójca nie chciał lub nie mógł zapłacić okupu i nikt za niego nie poręczył. Początkowo wysokość główszczyzny ustalały zwaśnione strony lub dokonywał tego wiec sądowy, potem rolę tę przejął władca, on też przejmował część opłaty w związku z naruszeniem pokoju powszechnego (fredus). Wysokość główszczyzny uzależniano od pozycji społecznej ofiary, pełnionego przez nią urzędu, a także od jej płci i wiekus . Pomimo prób ograniczenia krwawej zemsty przez władców, a później też Kościół utrzymywała się ona w społeczeństwach postbarbarzyńskich dosyć długo, bo aż do czasów nowożytnych (a w niektórych regionach Europy do dzisiaj, np. w Albanii, czy

${ }^{2}$ Najlepszy przykład próby zastąpienia krwawej zemsty główszczyzną znajdujemy w Prawdzie Ruskiej z XI w., w której podkreślono obowiązek wróżdy, a nawet dawano jej pierwszeństwo, ale w razie braku mściciela miała być zapłacona grzywna. Dokonano też ograniczenia kręgu uprawnionych do główszczyzny i zemsty (do najbliższych członków rodziny: ojca, syna, brata, bratanka i siostrzeńca). Natomiast w obszerniejszej i późniejszej wersji tego zwodu pierwszeństwo miał już okup; Prawda Russkaja, wyd. B.D. Grekow, t. 2, Moskwa-Leningrad 1947, art. 1 i art. 1-2; K. Modzelewski, Zemsta, s. 273-274. Podobnie rzecz ujęto w szwedzkim prawie zwyczajowym z XIII w. (Westgötalag), por. K. Modzelewski, Barbarzyńska Europa, s. 122. Z literatury ogólnej o wergeldzie zob. H. Brunner, Sippe und Wergeld in den niederdeutschen Rechten, „Zeitschrift der Savigny-Stiftung. Germanistische Abtheilung", 1882, Bd. 3, s. 1-101; K. Modzelewski, Barbarzyńska Europa, s. 119-158; A. Roth, Wergeld, [w:] Lexicon des Mittelalters, Tl. 8, München 1997, szp. 2199-2001. Natomiast o główszczyźnie w Polsce średniowiecznej najszerzej pisał A. Pawiński, O pojednaniu w zabójstwie wedlug prawa polskiego, Warszawa 1884; por. też J. Matuszewski, Główszczyzna chłopska i szlachecka, „Kwartalnik Historyczny” 1964, nr 1, s. 17-26.

${ }_{3}$ P. Cornelius Tacitus, Germania, przekł. T. Płóciennik, wstęp i komentarz J. Kolendo, Poznań 2008 , c. 21 , s. $78-79$.

${ }^{4}$ M. Klementowski, Powszechna historia ustroju, Warszawa 2012, s. 89.

${ }^{5}$ Główszczyzna kobiety, dziecka i urzędnika (drużynnika) zwykle była wyższa niż mężczyzny tego samego stanu (w prawie salickim trzykrotnie), podobnie wyższa była główszczyzna za zabójstwo rycerza lub chłopa (w Księdze elblaskiej odpowiednio 50 i 30 grzywien), por. Najstarszy zwód prawa polskiego, wyd. J. Matuszewski i J. Matuszewski, Łódź 1995, § 8.2, § 15.5 i § 15.13; Lex Salica, hrsg. von J.K.A. Eckhardt, Monumenta Germaniae Historica. Legum Sectio I. Legum nationum Germanicarum, T. IV, Pars II, Hannoverae 1969, art. XXIV, XLI.

${ }^{6}$ K. Modzelewski, Legem ipsam vetare non possumus. Królewski kodyfikator wobec potęgi zwyczaju, [w:] Historia, idee, polityka (ksiega dedykowana J. Baszkiewiczowi), Warszawa 1995, s. 26-32. Przykładowo kapitularze frankońskie przewidywały karę wygnania dla każdego, kto nie zgodziłby się przyjąć od sprawcy przestępstwa odszkodowania pieniężnego. 
na Sycylii). Z czasem nawet zapłata główszczyzny nie chroniła winowajcy przed dodatkowymi karami publicznymi, np. opłatą dodatkowej grzywny, otrzymaniem kary cielesnej, a w końcu w ogóle zniesiono możliwość wykupienia się od kary publicznej (Constitutio criminalis Carolina, 1532) ${ }^{7}$, nawet w przypadku pojednania się sprawcy z pokrzywdzonymi (czego ostatecznie zabroniono poza sądem $)^{8}$. Warto też podkreślić, że w przypadkach niewykrytych sprawców zabójstwa odpowiedzialność zbiorową ponosili wszyscy wolni mieszkańcy jednostki terytorialnej, w której dokonano przestępstwa (Księga elbląska, Ruska Prawda $)^{9}$. Także zabójstwo nieumyślne nie chroniło od główszczyzny, pierwotnie także od krwawej zemsty, dopiero w późniejszym czasie władza zwierzchnia w takim przypadku ustawowo jej zabraniała, nie pobierając też opłaty fredus ${ }^{10}$.

Przechodząc do główszczyzny w Prusach, odnotujmy, że pierwszą szerszą o niej wzmiankę opublikował Johannes Voigt, który opowiadał się za wprowadzeniem wergeldu przez Zakon, początkowo tylko dla warstwy witingów, a potem w XIV w. dla pojedynczych wolnych, wiernych i zasłużonych Prusów oraz przybyszów z Jaćwieży i Litwy. Upowszechnienie wergeldu dla wolnych miało nastąpić w drugiej połowie XIV w. Wyróżnił trzy stawki główszczyzny (16, 30, 60 grzywien), ale przyznawane według woli i łaski Zakonu, a nie w zależności od wielkości posiadanych dóbr. Podkreślił udział władców (Zakonu, biskupów i kapituł) wśród udziałowców wypłacanej główszczyzny i dopuszczał krewnych kognacyjnych w podziale okupu ${ }^{11}$. Najobszerniejsze dotąd opracowanie o główszczyźnie w Prusach dał George Adalbert von Mülverstedt, ale - co ciekawe - nie znał on wcześniejszej pracy J. Voigta ${ }^{12}$. Trzeba też zaznaczyć, że autor nie dotarł do wszystkich przywilejów zawierających wzmianki o główszczyźnie, głównie z terytorium późniejszych Mazur. Jego ustalenia ( $\mathrm{tj}$. wprowadzenie wergeldu na ziemie pruskie przez Zakon, wzmiankowanie główszczyzny tylko w przywilejach dla wolnych Prusów,

${ }^{7}$ Des allerdurchleuchtigsten großmechtigsten vnüberwindtlichsten Keyser Karls des fünfften: vnnd des heyligen Römischen Reichs peinlich gerichts ordnung auff den Reichsztägen zu Augspurgk vnd Regenspurgk inn jaren dreissig vnd zwey vnd dreisssig gehalten auffgericht vnd beschlossen, Mainz 1533, art. CXXXVII.

8 W. Litewski, Landrecht des Herzogtums Preussen von 1620. I. Strafrecht, WarszawaKraków 1982, s. 61-62; P. Frauenstädt, op. cit., s. 175.

9 Prawda Russkaja, art. 20; Najstarszy zwód prawa polskiego, § 8.3-4.

10 Edictus Rothari, ed. F. Bluhme, Monumenta Germaniae Historica. Legum, Bd. IV, Hannoverae 1868, s. 3-90; Leges Saxonum, ed. K. von Richthofen, K.F. von Richthofen, Monumenta Germaniae Historica. Legum, Bd. V, Hannover 1875, s. 47-84.

11 J. Voigt, Geschichte Preussens von den ältesten Zeiten bis zum Untergang der Herrschaft des Deutschen Ordens, Bd. 4, Königsberg 1830, Beilage II, s. 594-602. Wcześniej o wergeldzie autor ten dał krótką wzmiankę w swojej pracy Geschichte der Eidechsengesellschaft in Preussen, Königsberg 1823, s. 227-228.

12 G.A. von Mülverstedt, Beiträge zur Geschichte des Wergeldes in Preussen, „Der neuen Preussischen Provinzial-Blätter andere Folge" 3 (1853), s. 373-382, 390-413; ibidem, Bd. 4, s. 292. 
istnienie trzech stawek tej opłaty w zależności od wielkości dóbr, długie jej trwanie do XVII w., stosowanie rytuału gestów w ugodzie między rodami) W większości przyjęła późniejsza literatura. Z kolejnych autorów piszących na temat główszczyzny w Prusach, choć nie wprowadzających istotnych korekt w dotychczasowych ustaleniach, wspomnieć należy o Maxie Toeppenie, Henryku Łowmiańskim czy Dariuszu Adamie Sikorskim ${ }^{13}$. Nie uwzględniając badań G.A. von Mülverstedta, a jedynie J. Voigta, o wergeldzie na Sambii pisał ostatnio Grischa Vercamer. Nie wykluczał znajomości główszczyzny u Prusów w czasach przedkrzyżackich; uznał, że wysokość wergeldu może być dobrą miarą pozycji społecznej wolnych, choć podkreślał też, że główszczyzna obejmowała inne grupy społeczne (m.in. pruskich chłopów i ludzi luźnych); obok trzech stawek uzależnionych od pozycji społecznej (16, 30, 60 grzywien) wyróżnił jeszcze najniższą stawkę 8 grzywien (głównie dla chłopów i małych wolnych); zauważył, że jedną trzecią główszczyzny zagwarantował sobie Zakon; przyjął, że wergeld wspominano tylko w przywilejach dla dóbr wolnych i to tylko na prawie pruskim i magdeburskim ${ }^{14}$.

Zanim przejdziemy do główszczyzny w okresie panowania zakonu krzyżackiego, zastanówmy się nad pytaniem, czy znali ją Prusowie w okresie plemiennym? Badacze od czasu Voigta, von Mülverstedta i Toeppena odpowiadają w sposób jednoznaczny, że jedyną formą wymiaru sprawiedliwości w przypadku mężobójstwa znaną Prusom była krwawa wróżda, a główszczyznę wprowadził dopiero zakon krzyżacki ${ }^{15}$. Opierano to przede wszystkim na bezpośredniej wzmiance z kroniki Piotra z Dusburga i Mikołaja z Jeroszyna, że ,jeśli zostanie popełnione u nich zabójstwo, wówczas nie może dojść do żadnego pojednania, chyba że najpierw rodzice zamordowanego zabiją zabójcę lub jego krewnego. Kiedy z powodu nieoczekiwanego wypadku dochodzi do gwałtownych sporów, zazwyczaj nawzajem się wyrzynają"16. Drobną wąt-

13 Zob. M. Toeppen, Geschichte Masurens, Danzig 1870, s. 113 (ten fragment źle oddany w polskim thumaczeniu, idem, Historia Mazur, Olsztyn 1995, s. 120); idem, Exkurs über die Verschreibungen des Ordens für Stammprußen im 13. Jahrhundert, [w:] Scriptores rerum Prussicarum, hrsg. von T. Hirsch, M. Toeppen, E. Strehlke, Bd. 1, Leipzig 1861, s. 268-269; H. Łowmiański, Studia nad początkami spoleczeństwa i państwa litewskiego, t. 1, Wilno 1931, s. 419; D.A. Sikorski, Instytucje władzy u Prusów w średniowieczu (na tle struktury społecznej i terytorialnej), Olsztyn 2010, s. 146-147, który za Łowmiańskim podkreślał archaiczność formy krwawej zemsty u Prusów, nie dopuszczającej ugody.

${ }^{14}$ G. Vercamer, Siedlungs-, Sozial- und Verwaltungsgeschichte der Komturei Königsberg in Preußen (13.-16. Jahrhundert), Marburg 2010, s. 315-317.

15 J. Voigt, Geschichte Preussens, s. 594; G.A. von Mülverstedt, op. cit., s. 380, 391; M. Toeppen, Exkurs, s. 268-269; por. ostatnio D.A. Sikorski, op. cit., s. 146-147, 244; W. Długokęcki, Uwagi o genezie i rozwoju wczesnośredniowiecznych Prus do początków XIII wieku, „Pruthenia” 2 (2006), s. 28-29; idem, Instytucja wodzostwa u Prusów w XIII wieku, [w:] Instytucja ,wczesnego państwa” w perspektywie wielości i różnorodności kultur, red. J. Banaszkiewicz, M. Kara, H. Mamzer, Poznań 2013, s. 362.

16 Petrus de Dusburgk, Chronica terrae Prussiae, ed. J. Wenta et S. Wyszomirski, Monumenta Poloniae Historica. Nova series, t. 13, Kraków 2007, III, c. 5: Si homicidium committitur inter eos, 
pliwość w tej sprawie zasiał Henryk Łowmiański ${ }^{17}$, a ostatnio Grischa Vercamer $^{18}$. Sprawa pozostaje otwarta do czasu szczegółowych badań ${ }^{19}$. Wstępnie należy podkreślić, że wydaje się czymś niezwykłym, aby u Prusów nie były znane i stosowane alternatywne drogi załatwienia sporu, przede wszystkim poprzez ugodę i okup w naturze. Jak wspomniano, tego typu normy znane były u Germanów już w I w. n.e., były też znane i rozpowszechnione u większości ludów tradycyjnych, nawet tych najprymitywniejszych, bez zorganizowanej władzy ${ }^{20}$. Natomiast w świetle przekazu Piotra z Dusburga nie ulega wątpliwości, że u Prusów wyraźnie dominującą formę wymiaru sprawiedliwości w przypadku zabójstw musiała stanowić nadal wróżda.

Można również przyjąć, że przynajmniej zwyczaj pieniężnej główszczyzny został wprowadzony przez Krzyżaków. Chodziło im w tym przypadku o całkowite zapobieżenie krwawej wróżdzie rodowej, która dotykała przecież także zwolenników Zakonu. Wydaje się jednak, że w okresie podboju Prus, a zarazem kształtowania się zakonnego władztwa, pozostawiano Prusom wybór między stosowaniem tradycyjnej krwawej zemsty (wróżdy) a wergeldem. W nadaniu z $1261 \mathrm{r}$. dla Prusa Geduna zapisano: is, qui necis reus fuerit, collum pro collo, manum pro manu reddere teneatur, tamen suorum arbitrii sit permutare, si pro eo decreuerint aliquam summam pecuniae acceptare ${ }^{21}$, podobnie w późniejszym przywileju z 1284 dla Bliwota czytamy, że jeśli: quis vero ipsum, quod absit, occiderit aut membrum mutilaverit, reus huius facti collum pro collo aut manum pro manu reddet. Tamen in suorum arbitrio

nulla potest compositio intervenire, nisi prius ille homicida vel propinquus eius ab occisi parentibus occidatur. Quando ex inopinato rerum eventu aliquam immoderatam incurrerunt turbationem, se ipsos occidere consueverunt; polskie thumaczenie Piotr z Dusburga, Kronika ziemi pruskiej, przetłumaczył S. Wyszomirski, wstępem i komentarzem opatrzył J. Wenta, Toruń 2004, s. 45. Natomiast przekaz Mikołaja z Jeroschina zob. Di Kronike von Pruzinlant des Nicolaus von Jeroschin, hrsg. von E. Strehlke, [w:] Scriptores rerum Prussicarum, Bd. 1, s. 350-351; por. Ł. Okulicz-Kozaryn, Dzieje Prusów, Wrocław 1997, s. 317.

${ }_{17}$ H. Łowmiański, Prusy pogańskie, [w:] idem, Prusy - Litwa - Krzyżacy, Warszawa 1989 (pierwsze wyd. Toruń 1935), s. 76, przyjmował istnienie okupu jako starego zwyczaju prawnego tylko w przypadku mniejszego przestępstwa, powołując się na przywilej Geduna z 1261 r., zob. niżej. Przywilej ten jednak wyraźnie wskazuje na możliwość zastąpienia wróżdy za zabójstwo okupem, natomiast brakuje przesłanek co do czasu pojawienia się tego zwyczaju.

18 G. Vercamer, op. cit., s. 315.

19 Autor oparł swoje wątpliwości na wzmiance z przywileju dla Luprechta (przy tym błędnie podaje, że z drugiej połowy XIII w.), Preußisches Urkundenbuch [dalej: PU], Bd. II, 2, hrsg. von M. Hein, E. Maschke, Königsberg 1939, Nr. 628 (1328 r.), z niego jednak nie wynika, że wergeld był znany Prusom w epoce pogańskiej, ale występował w prawie „starych witingów”, które wcale nie musiało mieć metryki sprzed podboju.

${ }^{20}$ Por. J. Kurczewski, op. cit., s. 8-16, 111, 173, 284-285. Dużą rolę odgrywały w tym wspólnoty sąsiedzkie, które naciskały na wzajemną ustępliwość stron, nie chcąc doprowadzić do dezintegracji środowiska.

${ }^{21}$ Codex diplomaticus Warmiensis, hrsg. von C.P. Woelky, J.M. Saage, Bd. 2, Mainz 1864, Nr. 520. 
sit parentum, si pro ipso pecuniam voluerint acceptare ${ }^{22}$. Zatem to Prusowie mieli sami zdecydować, w zależności od uznania i doraźnego interesu, w jaki sposób powetują sobie doznane krzywdy, czy będą nadal stosować krwawą zemstę, czy też poprzez ugodę zapłacą wergeld ${ }^{23}$. Najwyraźniej Zakon nie był w stanie znieść od razu starego i mocno ugruntowanego zwyczaju wróż$\mathrm{dy}^{24}$, a ponadto opłata wergeldu nie została wprowadzona jakąś ogólną i jedną normą prawną, ale była regulowana każdorazowo w przywilejach. Niemniej jednak w XIV w. ustalił się pewien ogólny wzorzec, przynajmniej w zakresie wysokości opłaty ${ }^{25}$. Na jeszcze jedną rzecz warto zwrócić uwagę, powyższe wzmianki z przywilejów nie wykluczały możliwości krwawej zemsty na mężobójcach z innych grup etnicznych, a więc też na Niemcach czy Polakach.

Przechodzimy do kolejnej tezy przyjmowanej w literaturze przedmiotu, że główszczyzna wzmiankowana była tylko w nadaniach dla wolnych Prusów (Freie) i tylko ich dotyczyła ${ }^{26}$. Pojawianie się wzmianki o wergeldzie tylko u Prusów thumaczy się tym, że dla Polaków i Niemców była to norma od dawna znana i oczywista, zaś w przypadku Prusów musiała być w ten sposób utrwalana $^{27}$. J. Voigt przypuszczał, że pojawienie się wergeldu związane było bezpośrednio z warstwą witingów na Sambii, którym Krzyżacy mieli zapewnić $\mathrm{w}$ ten sposób ochronę i bezpieczeństwo ${ }^{28}$. M. Toeppen słusznie wątpił, aby dotyczyć to miało tylko witingów ${ }^{29}$, szerzej zagadnienia nie wyjaśniając. Ale czy to założenie o warstwie społecznej wolnych Prusów jest słuszne i czy oznaczało to, że z opłaty tej wyłączone zostały inne warstwy społeczne i inne grupy etniczne? Dotychczasowa historiografia nie podjęła w zasadzie tematu. Jedynie G. Vercamer przyjął, że główszczyznę wnosiły różne warstwy społeczne, w tym też pruscy chłopi, a przez analogię z Rzeszą też tzw. ludzie

22 PU, Bd. 1, 2, hrsg. von A. Seraphim, Königsberg 1909, Nr. 435; H. Łowmiański, Studia nad poczatkami społeczeństwa, s. 420; inne przykłady podał też J. Voigt, Geschichte Preussens, s. 601.

${ }^{23}$ A. Dobrosielska, G. Białuński, Dyskretny urok źródeł czyli o aktualności pracy Maxa Toeppena ,Exkurs über die Verschreibungen des Ordens für Stammprußen im 13. Jahrhundert”, „Pruthenia" 8 (2013), s. 214; H. Łowmiański, Studia nad początkami społeczeństwa, s. 253.

${ }^{24}$ Tak też D.A. Sikorski, op. cit., s. 244, wbrew zdaniu H. Łowmiańskiego (Studia nad początkami społeczeństwa, s. 420), który przyjmował „łatwe” stłumienie wróżd rodowych.

${ }^{25}$ M. Toeppen, Exkurs, s. 269.

${ }^{26}$ G.A. von Mülverstedt, op. cit., s. 381-382, 390-393; W. Kętrzyński, O ludności polskiej w Prusiech niegdyś krzyżackich, Lwów 1882, s. 267-268, podkreślając brak wzmianek o główszczyźnie u Polaków i Niemców; P. Germerhausen, Siedlungsentwicklung der preussischen Ämter Holland, Liebstadt und Mohrungen vom 13. bis 17. Jahrhundert, Marburg/Lahn 1970, s. 30, 33: który stwierdził, że wergeld „musste gezahlt werden, wenn ein prussischer Freier erschlagen wurde"; G. Białuński, Osadnictwo regionu Wielkich Jezior Mazurskich od XIV do początków XVIII wieku. Starostwa leckie (giżyckie) i ryńskie, Olsztyn 1996, s. 50, 136.

${ }^{27} \mathrm{~L}$. Weber, Preussen vor 500 Jahren in culturhistorischer, statistischer und militarischer Beziehung, nebst Special-Geographie, Danzig 1878, s. 298; G.A. von Mülverstedt, op. cit., s. 390-393 .

28 J. Voigt, Geschichte Preussens, s. 594.

${ }^{29}$ M. Toeppen, Exkurs, s. 269. 
luźni, np. najemni robotnicy ${ }^{30}$. Tymczasem nawet pobieżny przegląd źródeł pozwala stwierdzić, wbrew dotychczasowej literaturze ${ }^{31}$, że wzmianki o wergeldzie znajdujemy także w przywilejach na prawie chełmińskim, w tym dla Niemców i Polaków ${ }^{32}$. Wiadomo nadto, że wzmiankę o główszczyźnie podawano $\mathrm{w}$ przywilejach dla wolnych pochodzenia litewskiego ${ }^{33}$. Z innych źródeł wnosimy ponadto, że Niemcy i Polacy płacili główszczyznę, choćby nie posiadali wzmianki o tym w przywilejach, w tym także mieszczanie, karczmarze i młynarze ${ }^{34}$. Przy tym zezwolenie w dokumencie na główszczyznę było uważane za szczególne wyróżnienie i przywilej, co podkreślają dodatkowe wzmianki z dokumentów: aus besondern Gnaden. Nie wszyscy też wolni otrzymywali na nią zgodę w przywilejach, a wręcz niektórzy o taką zgodę niekiedy zabiegali ${ }^{35}$. W takich przypadkach chodziło najpewniej o otrzymanie wyższej stawki wergeldu. Sama norma pieniężnego okupu upowszechniła się bowiem i stała się czymś oczywistym, nawet bez wzmianki o tym w przywileju ${ }^{36}$, co potwierdza też Iura Prutenorum (wtedy wynosiła ona 8 grzywien) ${ }^{37}$. Podsumowując, można stwierdzić, że wzmianki o wergeldzie dominują w przywilejach wolnych Prusów, ale znajdują się też wzmianki dla wolnych pochodzenia litewskiego, polskiego i niemieckiego. Główszczyzna była powszechna i dotyczyła wszystkich wolnych warstw społecznych, nawet bez wzmianek o niej w przywilejach, a to ostatnie stanowiło swoiste wyróżnienie.

Tutaj pojawia się kolejne pytanie, na które w literaturze przedmiotu w zasadzie nie odpowiedziano, mianowicie, czy główszczyzna w Prusach dotyczyła wszystkich zabójstw, również tych przypadkowych? ${ }^{38} \mathrm{~W}$ świetle dotąd

${ }^{30}$ G. Vercamer, op. cit., s. 315 i przyp. 1991.

31 W. Kętrzyński, op. cit., s. 267-268; ostatnio G. Vercamer, op. cit., s. 316, 401.

${ }^{32}$ Doskonałym tego przykładem jest przywilej dla Orła w okręgu ryńskim z lat 1437 i 1538, Geheimes Staatsarchiv Preußischer Kulturbesitz, Berlin, XX. Hauptabteilung [dalej: GStPK], Ordensbriefarchiv, Nr. 2434 oraz GStPK, Ostpreußische Folianten, Nr. 332, f. 10-11. Wśród mieszkańców w 1437 r. znajdujemy Polaków (rodzinę Budzyńskich z Mazowsza), ale też prawdopodobnie Niemców (rodzinę Stegelitz, najpewniej z Brandenburgii) i być może Prusów, por. G. Białuński, Osadnictwo, s. 43. W XVI w. zdecydowanie przeważali już Polacy (o czym świadczą imiona i nazwiska, podaję w zapisie oryginalnym: Grzegors, Michal, Zamoray, Martzin, Tomeck, Jan Stronnila, Micolay, Gentosch, Borutha, Voiteck, Jan Schwietz, itp.), GStPK, Ostpreußische Folianten, Nr. 911a 29 (1540 r.).

33 PU, Bd. 2, 2, Nr. 798 (1333 r.); G. Vercamer, op. cit., s. 315, przyp. 1993.

${ }^{34}$ Iura Prutenorum, wyd. J. Matuszewski, Torun 1963, art. 18; Księga tawnicza Starego Miasta Torunia (1428-1456), wyd. K. Ciesielska, J. Tandecki, cz. 1-2, Toruń 1992-1993, nr 44, 118, 561, 590, 1046, 1214, 1238, 1370, 1467, 1638 (tutaj wzmiankowany niewątpliwie Polak - Schwartze Staske).

35 G. Vercamer, op. cit., s. 316, przyp. 2001.

${ }^{36}$ Tak już J. Voigt, Geschichte Preussens, s. 596-597. Rzadkością były odmowy wergeldu w przywileju, por. G. Vercamer, op. cit., s. 316, przyp. 2002.

37 Iura Prutenorum, art. 18; G. Vercamer, op. cit., s. 401.

${ }^{38}$ Kwestie podniósł już J. Voigt, Geschichte Preussens, s. 601, ale bez jednoznacznej odpowiedzi. 
zebranego materiału nie sposób na nie udzielić jednoznacznej odpowiedzi, jedynie z braku wykluczenia takich przypadków, np. w Iura Prutenorum, jak też $\mathrm{w}$ świetle analogii z prawami germańskimi i w Niemczech średniowiecznych można tak przyjmować, przynajmniej dla początkowego okresu władztwa krzyżackiego w Prusach ${ }^{39}$. Jednak od schyłku XIV w. zabójstwa umyślne nie podlegały już karze, natomiast utrzymano w mocy główszczyznę za zabójstwa dokonane przez zwierzę właściciela ${ }^{40}$. Opłata wergeldu dotyczyła też przypadków uszkodzenia ciała (pobicia, zranienia), jak też kradzieży czy zniewag, a nie tylko za zabójstwa, ale wtedy była to najpewniej indywidualna opłata należna poszkodowanemu od winowajcy, bez udziału grupy krewniaczej $^{41}$. Wówczas też po polsku odszkodowanie to powinniśmy określać mianem nawiązki, zaś po niemiecku także jako Busse $^{42}$.

O główszczyźnie u Prusów wspomina szczegółowo Iura Prutenorum (około 1340 r.): Wirt eyn man todgeslagen [...] wirt seyn wergelt den frunden gegeben (,,jeśli zabije się człowieka [...] przyznaje się jego główszczyznę krewnym") ${ }^{43}$. W przypadku zabójstwa osoby społecznie równej sobie płacono wysokość swojego wergeldu, w przypadku gdy śmierć poniosły obie strony, to wergeld był wypłacany nawzajem krewnym ${ }^{44}$. Nawet jeśli ofiarą zabójstwa był brat, to winny płacił wergeld swojej rodzinie, jak za obcego (pierwotnie mogło to być połączone z wykluczeniem zabójcy z rodu) ${ }^{45}$. Ciekawie brzmi artykuł z prawa pruskiego o zabójstwie braci bliźniąt, wyjaśniający, że za każdego z nich należało płacić odszkodowanie osobno ${ }^{46}$. Wydaje się oczywiste, ale widocznie $\mathrm{w}$ tradycji pruskiej było odwrotnie i bliźnięta traktowano jako jedność ${ }^{47}$, stąd pojawiła się potrzeba zapisu tej normy prawnej. Przy zabójstwie osoby niższego lub wyższego stanu płacono główszczyznę według godności danej osoby (zatem odpowiednio albo niższy, albo wyższy wergeld) ${ }^{48}$. Podwójną stawkę główszczyzny zasądzano za naruszenie wcześniejszej ugody między stronami, niezależnie od tego, czy była to strona sprawcy, czy winne-

${ }^{39}$ K. Koranyi, Powszechna historia prawa, Warszawa 1976, s. 44, 89, 117, 164.

40 Das alte Kulmische Recht, mit einem Wörterbuche, hrsg. von C.K. Leman, Berlin 1838, Buch V, XV-XVII, XXV; Prawo starochetmińskie 1584 (1394), red. W. Maisel, Z. Zdrójkowski, przekład A. Bzdęga, A. Gaca, Toruń 1983, ks. V, art. 15-17, 25.

${ }^{41}$ Iura Prutenorum, art. 103, 108; J. Voigt, Geschichte Preussens, s. 598-601; M. Bloch, op. cit., s. 151; K. Modzelewski, Barbarzyńska Europa, s. 125.

${ }^{42}$ K. Kamińska, Prawo chetmińskie w świetle najstarszych ksiag miejskich Chetmna i Torunia (XIV i XV w.) [w:] Studia Culmensia historico-juridica czyli księga pamiatkowa 750-lecia prawa chetmińskiego, t. 1, red. Z. Zdrójkowski, Toruń 1990, s. 350; Das alte Kulmische Recht, s. 265-266 .

43 Iura Prutenorum, art. 103.

44 Ibidem, art. 12.

45 Ibidem, art. 13.

${ }^{46}$ Ibidem, art. 84.

47 Por. m.in. rozważania J. Suchockiego, Mitologia bałtyjska, Warszawa 1991, s. 100-102.

48 Iura Prutenorum, art. 14. 
$\mathrm{go}^{49}$. Wydaje się, że poprzez analogię ze stawkami za zranienie można przyjąć, że główszczyzna kobiety była podwójna ${ }^{50}$. Zabójstwo dokonane przez urzędnika (np. komornika lub gońca) w czasie pełnienia służby i w celu wykonania zadania nie podlegało karze $^{51}$. Gdy do określonego zabójstwa przyznała się więcej niż jedna osoba, nie zsumowywano stawki okupu, ale każdy płacił oddzielnie całą stawkę ${ }^{52}$. Odbiega to od normy stosowanej w sądach miejskich, według której kilka osób uczestniczących w przestępstwie, solidarnie płaciło jedną karę pieniężną ${ }^{53}$. Wysokość okupu nie zależała od liczby ran, które spowodowały śmierć. Jednak jeśli sprawca zabójstwa otrzymał rany lub okaleczenia od zabitego, to dziedzice zmarłego (dosłownie: der tode, czyli sam zmarły) winni zapłacić nawiązkę ${ }^{54}$. Tyle przepisy szczegółowe.

Do tej pory przyjmowano istnienie tylko trzech stawek wergeldu 16, 30 i 60 grzywien, które miałyby też odzwierciedlać trójpodział społeczeństwa pruskiego ${ }^{55}$. Przyjmowano też na ogół, że wysokość opłaty zależała od wielkości dóbr służebnych. I tak, 16 grzywien otrzymywali właściciele dóbr do 5 łanów (radeł), 30 grzywien do 10 łanów (radeł) i powyżej 10 łanów (radeł) 60 grzywien $^{56}$. Słuszniejsze wydaje się jednak zdanie J. Voigta, że stawka wergeldu nie była ściśle uzależniona od wielkości dóbr, ale bardziej zależała od decyzji władz ${ }^{57}$. Ostatnie badania G. Vercamera w zasadzie to potwierdzają, uzupełniając, że główne znaczenie odgrywała pozycja społeczna zajmowana przez osobę pozbawioną życia ${ }^{58}$. Najpopularniejszą stawką na Sambii około 1400 r. stanowiło 16 grzywien (około 87\%), na ogół posiadali oni majątki liczące od 2 do 4 radeł. Obdarzeni główszczyzną w wysokości 30 grzywien (około 10\%) posiadali majątki od 4 do 15 radeł (do tego dochodziło niższe, rzadziej wyższe sądownictwo). Pozostali wolni otrzymali główszczyznę w wysokości 60 grzywien (3\%) i posiadali dobra liczące prawie bez wyjątku od 10 radeł (wraz z prawem wyższego sądownictwa). W nich widzi autor przyszłych tzw. wielkich wolnych (obok nielicznych właścicieli znaczniej-

49 Ibidem, art. 105; chodzi o ugodę po zaistniałym wcześniej zabójstwie, potwierdzenie tego znaleźć można w art. 108.

${ }^{50}$ Ibidem, art. 85.

51 Ibidem, art. 100.

52 Ibidem, art. 79; tak też przyjmuje W.T. Paszuto, Pomezanija. „Pomiezanskaja Prawda” kak istoriczeskij istocznik izuczenija obszczestwiennogo i politiczeskogo stroja Pomiezanii XIII-XIV ww., Moskwa 1955, s. 99.

${ }^{53}$ K. Kamińska, Prawo chetmińskie, s. 351.

${ }^{54}$ Iura Prutenorum, s. 124.

${ }_{55}$ R. Wenskus, Über einige Probleme der Sozialordnung der Prußen, [w:] idem, Ausgewählte Aufsätze zum frühen und preußischen Mittelalter. Festgabe zu seinem siebzigsten Geburtstag, Sigmaringen 1986, s. 422.

56 G.A. von Mülverstedt, op. cit., s. 394; G. Białuński, Osadnictwo, s. 50.

57 J. Voigt, Geschichte Preussens, s. 598-601.

${ }^{58}$ Tak też K. Kamińska, Prawo chetmińskie, s. 351; A. Szorc, Dominium warmińskie 1243-1772. Przywilej i prawo chetmińskie na tle ustroju Warmii, Olsztyn 1990, s. 406. 
szych dóbr na prawie chełmińskim, w sumie około 5\% wolnych $)^{59}$. Przynależną sobie od pokoleń wysokość główszczyzny należało w razie potrzeby dowieść poprzez współprzysiężników lub dokumentami ${ }^{60}$.

Wydaje się, że należy wyróżnić przynajmniej jeszcze jedną powszechnie stosowaną stawkę 8 grzywien. Potwierdza ją też Alojzy Szorc i Georg Matern na Warmii ${ }^{61}$ oraz G. Vercamer na obszarze Sambii, odnosząc ją przede wszystkim do pruskich chłopów, ale też małych wolnych bez odpowiedniej wzmianki o wergeldzie $\mathrm{w}$ przywileju ${ }^{62}$. Taką stawkę potwierdzono również w przywileju z 1478 r. dla wolnych w Kalu, w okręgu węgorzewskim ${ }^{63}$. G.A. von Mülverstedt podał także przykłady stosowanych jeszcze dwóch innych stawek: 10 i 20 grzywien, a J. Voigt stawki 32 grzywien $^{64}$, z kolei w Iura Prutenorum wspomniano stawkę 12 grzywien ${ }^{65}$. Zbliżone stawki główszczyzny były orzekane przez sądy Torunia i Chełmna w wiekach XIV i XV. Tutaj najniższa odnotowana stawka wynosiła 4, a najwyższa 30 grzywien $^{66}$. W Prawie starochełmińskim pełna główszczyzna mieszczanina została określona na 18 funtów magdeburskich, czyli 30 pruskich grzywien ${ }^{67}$, również w Iura Prutenorum podstawowa stawka dla wolnych właścicieli dziedziny, niezależnie czy Prusa, czy Niemca, we wsi i w mieście, wynosiła 30 grzywien $^{68}$. Za zabicie luźnego Niemca, bez ogrodu i dziedziny, płacono 8 grzywien, za Niemca zagrodnika 12 grzywien. Mieszczanie wielkich miast pruskich, takich jak Gdańsk i Toruń, uzyskali dla swoich obywateli główszczyznę równą szlacheckiej (od 1627 r.) ${ }^{69}$. W XVII stuleciu w związku z deprecjacją monety

59 G. Vercamer, op. cit., s. 317, 401.

${ }^{60}$ Iura Prutenorum, art. 64.

${ }^{61}$ A. Szorc, op. cit., s. 406; por. G. Matern, Um Hals und Hand. Beiträge zur Geschichte der Rechtspflege im Ermland, Braunsberg 1912, s. 33-34.

${ }^{62}$ G. Vercamer, op. cit., s. 315-316, 401.

${ }^{63}$ GStPK, Ostpreußische Folianten, Nr. 124, f. 220. Przywilej drukowany w: E. Gudlat, Kehlen. Geschichte und Entwicklung, Rotenburg 1973, s. 201-203.

${ }^{64}$ G.A. von Mülverstedt, op. cit., s. 394; J. Voigt, Geschichte Preussens, s. 598.

65 Iura Prutenorum, art. 18.

${ }^{66}$ K. Kamińska, Prawo chetmińskie, s. 350-351; Księga tawnicza Starego Miasta Torunia, nr 118 (12 grzywien), 590 (14 grzywien), 1046 (8 grzywien), 1214 (24 grzywny), 1238, 1467 (po 20 grzywien), 1370 (9 grzywien), 1638 (4 grzywny).

${ }^{67}$ Das alte Kulmische Recht, Buch II, XXXVII, LIII, Buch III, XXXV; Prawo starochetmińskie 1584 (1394), ks. II, art. 37, 53, ks. III, art. 35; taką też stawkę stosowano w ławie miasta Chełmna, E. Steffenhagen, Deutsche Rechtsquellen in Preussen vom XIII. bis zum XVI. Jahrhundert, Leipzig 1875, s. 45. O równowartości 30 grzywien pruskich z 18 funtami magdeburskimi, zob. wyliczenia i uzasadnienie M. Dygo, ,Hospites eciam eo iure fruantur, quo et milites Mazouienses”. W sprawie lokacji Płocka w 1237 roku, „Kwartalnik Historyczny” 1993, nr 3, s. 16-17.

68 Iura Prutenorum, art. 18, 64; G. Vercamer, op. cit., s. 316; A. Szorc, op. cit., s. 406: „gdyby ktoś z podpuszczenia diabła takiego Prusa [tj. wolnego] zabił, zapłaci 30 grzywien".

${ }^{69}$ S.M. Szacherska, Próba walki o główszczyznę mieszczańska w XV w. [w:] „Cultus et cognito”. Studia z dziejów średniowiecznej kultury, red. S.K. Kuczyński i in., Warszawa 1976, s. 556; D. Janicka, Prawo karne w trzech rewizjach prawa chetmińskiego z XVI wieku, Torun 1992, s. 55. 
w Prusach wysokość główszczyzny uległa wyraźnej zmianie, wzrosła nawet do 700 grzywien w przypadku szlachcica $(1614 \text { r. })^{70}$. G.A. von Mülverstedt błędnie uważał ponadto, że główszczyzna nie występowała na całym obszarze Prus, nie znał takich wzmianek np. dla okręgów szczycieńskiego, ełckiego i węgorzewskiego ${ }^{71}$. Dzisiaj dowodnie znamy je także dla okręgu okolic Szczytna i Węgorzewa, poza tym opłata ta występowała sporadycznie również w okręgach giżyckim i ryńskim ${ }^{72}$. Faktycznie nie wspomniano wergeldu w nadaniach tylko dla okręgu ełckiego, ponadto straduńskiego i piskiego, ale tutaj osadnictwo pruskie było skromne, a przede wszystkim była to dosyć późna akcja kolonizacyjna (XV-XVI w. $)^{73}$.

Wysokość okupu nie była niska. Przykładowo w 1340 r. pewien wolny z Sambii dla spłaty główszczyzny w wysokości 60 grzywien zmuszony był sprzedać biskupowi swoje dobra i majątek liczący 4 radła. Na prośbę wielu innych wolnych biskup zgodził się na pozostawienie 1 radła jego dziedzicom, choć na innym terytorium ${ }^{74}$. Niekiedy zapłatę wysokiej główszczyzny zabezpieczano przez ustanowienie zastawu na majątku przestępcy ${ }^{75}$. Zatem koszty były naprawdę wysokie. Dla porównania w Polsce za głowę szlachcica płacono w końcu XIV w. 60 grzywien, co było równowartością 2-3 włók ziemi uprawnej, albo 50 wołów, albo 40 koni, albo 720 korców pszenicy, albo 960 korców żyta, albo też 1440 korców owsa ${ }^{76}$. Z czasem, zwłaszcza w XV w. realna wartość pieniądza spadła, a stawki wergeldu utrzymywały się na tym samym poziomie, zgodnym z przywilejem. Stąd chyba wynikała obserwacja mnicha kartuskiego Henryka Beringera (1427/1428), że zabójstwa u Prusów były bardzo popularne, bo wystarczyło okupić się niewielką sumą pieniędzy (jakoby mniejszą niż cena konia) ${ }^{77}$.

Cała suma wergeldu była wypłacana tylko w przypadku zabójstwa, w razie zranienia lub innego uszkodzenia należna była odpowiednia, propor-

${ }^{70}$ G.A. von Mülverstedt, op. cit., s. 410. Podobny proces zauważamy w Rzeczypospolitej, w której już pod koniec XVI w. główszczyzna szlachecka wynosiła 240 lub w zależności od okoliczności zabójstwa nawet 480 grzywien, por. S.M. Szacherska, op. cit., s. 556.

${ }^{71}$ G.A. von Mülverstedt, op. cit., s. 393.

72 E. Saborowski, Besiedlung und Nationalitätenverhältnisse des Hauptamtes Ortelsburg (zur Zeit der Herrschaft des Deutschordens), Mitteilungen der Literarischen Geselschaft Masovia, 1925, Heft 30, s. 155; G. Białuński, Osadnictwo, s. 24, 50, 136.

${ }^{73}$ G. Białuński, Bevölkerung und Siedlung im ordensstaatlichen und herzoglichen Preussen im Gebiet der „, Grossen Wildnis” bis 1568, Hamburg 2009, s. 33-163, 205-215.

74 J. Voigt, Geschichte Preussens, s. 602; G. Vercamer, op. cit., s. 316-317; PU, Bd. 3, 1, Nr. 303.

75 Das alte Kulmische Recht, Buch III, XXIII; Prawo starochetmińskie 1584 (1394), ks. III, art. 23; K. Kamińska, Prawo chetmińskie, s. 351.

${ }^{76}$ A. Pawiński, op. cit., s. 30.

77 Die Ermahnung des Carthäusers, hrsg. von T. Hirsch, [w:] Scriptores rerum Prussicarum, Bd. 4, Leipzig 1870, s. 462-463. Na początku XV w. Zakon płacił odszkodowanie wolnym za utracone w wyprawie wojennej konie do 12 grzywien, por. G. Vercamer, op. cit., s. 315. 
cjonalna do szacunku szkody część tej sumy ${ }^{78}$. Najprawdopodobniej pierwotnie suma okupu w całości przypadała krewnym zabitego ${ }^{79}$, w tej samej kolejności co w przypadku spadkobrania ${ }^{80}$. Potem była dzielona między Zakon, ewentualnie biskupa i kapitułę oraz współrodowców zabitego w proporcjach $1 / 3$ do $2 / 3^{81}$. Zapewne była to część opłaty znanej w świecie germańskim pod nazwą fredus, a na Rusi wira. O należnej części z główszczyzny dla odpowiedniej władzy wspomina też Iura Prutenorum ${ }^{82}$. Natomiast w sądach miejskich zabójca obok główszczyzny wnosił opłatę na rzecz sędziego, zwaną mulktą (Gewette $)^{83}$. Zwyczajowo bowiem ugoda i wypłata główszczyzny następowała przed sądem, który ustalał też czas zapłaty (od 6 do 12 tygodni) $)^{84}$.

Główszczyzna w pierwszej kolejności należała do najbliższych krewnych $^{85}$. Wątpliwości budzi kwestia, czy tylko męskich krewnych w linii ojcowskiej (agnacyjnej), czy też w linii macierzyńskiej (kognacyjnej)? Dotąd jedynie J. Voigt odpowiedział na to pytanie pozytywnie ${ }^{86}$. Wydaje się, że była to norma powszechna ${ }^{87}$, z tendencją do stałego kurczenia się kręgu uprawnionych ${ }^{88}$. Pierwszeństwo w przyjęciu główszczyzny posiadali zapewne męscy

78 G. Vercamer, op. cit., s. 315; PU, Bd. 2, 2, Nr. 798. Według Prawa starochelmińskiego za zranienie płacono połowę pełnej główszczyzny (tj. 9 funtów magdeburskich=15 grzywien), Das alte Kulmische Recht, Buch II, LIX, Buch III, XXXVI; Prawo starochetmińskie 1584 (1394), ks. II, art. 59, III, art. 36; E. Steffenhagen, op. cit., s. 39.

${ }^{79}$ Iura Prutenorum, art. 103: freunde.

${ }^{80}$ Potwierdzenie tego mamy na Litwie, por. H. Łowmiański, Studia nad poczatkami społeczeństwa, s. 420.

${ }^{81}$ PU, Bd. 5, 2, hrsg. von K. Conrad, Marburg 1973, Nr. 90, przywilej z 1352 r. dla Luprechta. Zauważył to już J. Voigt, Geschichte Preussens, s. 601-602; por. W.T. Paszuto, Pomezanija, s. 96, G. Vercamer, op. cit., s. 315-316.

82 Iura Prutenorum, art. 12.

${ }^{83}$ Das alte Kulmische Recht, Buch II, m.in. XXXI, XXXII, XXXVI, XXXVII, LII; Prawo starochetmińskie 1584 (1394), m.in. ks. II, art. 31, 32, 36, 37, 52; K. Kamińska, Prawo chetmińskie, s. 351.

${ }^{84}$ Das alte Kulmische Recht, Buch II, XXXI, XXXVII, LVI-LVIII; Prawo starochetmińskie 1584 (1394), ks. II, art. 31, 37, 56-58; K. Kamińska, Prawo chetmińskie, s. 351.

85 J. Voigt, Geschichte Preussens, s. 602.

${ }^{86}$ Ibidem, s. 602.

${ }^{87}$ Por. przykłady ze świata germańskiego, K. Modzelewski, Barbarzyńska Europa, s. 128-154; H. Brunner, op. cit., np. s. 18, 24, 32-33, 59-60. Na to zdaje się wskazywać też najdawniejsze zwyczajowe prawo chełmińskie, por. S. Estreicher, O źródtach najdawniejszego prawa chetmińskiego. [Nieznany zwód mazowiecki będący kompilacja najstarszych ortyli chetmińskich z XIII i XIV wieku] [w:] Studia Culmensia historico-iuridica, t. 1, s. 154, a zwłaszcza zwrot w przypadku główszczyzny za bratobójstwo, która miała przypadać kościołowi: ecclesie non amicis, non patri, nec matri. Potwierdza to także dokument z 1499 r. cytowany przez G.A. von Mülverstedta (op. cit., s. 405-406) o ugodzie po zabójstwie między Janem Zincke a braćmi von Wargeln, w której stronami byli ich krewni (Freundschaft), najwyraźniej z obu linii (po stronie Zincke byli to przedstawiciele rodzin: von Gröben, Tale, Baricke i von Sirgieten, zaś po stronie braci Wargen: Canewitz, Hohendorf, Lirche, Seidell, Zacherau i von der Trencke).

${ }^{88}$ M. Bloch, op. cit., s. 159; S. Ciszewski, op. cit., s. 25 i nn. 
krewni w linii po mieczu, potem nie wykluczano też kobiet, a zwłaszcza matek i córek, o czym świadczą m.in. zapisy w Prawie starochetmińskim ${ }^{89}$.

Już G.A. von Mülverstedt zwrócił uwagę, że oprócz wnoszonej główszczyzny sprawca wraz ze współrodowcami w wyniku zawartej ugody z krewnymi zabitego miał też dodatkowe obowiązki i gesty do wykonania, takie jak publiczne błaganie krewnych zabitego o przebaczenie (często klęcząc, z wyciągniętymi rękoma lub nagim mieczem w ręku), zamówienie odpowiednich mszy za duszę zabitego, odbycie pokuty kościelnej, udanie się z pielgrzymką w święte miejsce, np. do Rzymu ${ }^{90}$ czy Composteli, ufundowanie pamiątkowych przedmiotów kultu, np. krzyży lub obrazów w parafii ${ }^{91}$. Wynikało to z faktu, że do zawarcia ugody konieczny był nadto tzw. akt pokory, czyli rytuał kary honorowej. Przybierał on najczęściej formę hołdu ,ust i rąk” (błaganie o przebaczenie, na klęczkach i z wyciągniętymi rękoma). W tej karze stronami bywały również grupy krewnych, a nie winne jednostki ${ }^{92}$. Zwyczaj wywodził się z czasów pogańskich i niewątpliwie nosił znamiona sakralne. W średniowiecznej Polsce to publiczne wyznanie winy i prośba o odpuszczenie nosiła nazwę ,pokory" 93 .

Główszczyzna stosowana była bardzo długo. W 1436 r. stany na pytanie wielkiego mistrza: czy pozostawić wergeld, czy poszukać innej formy sprawiedliwości w przypadku zabójstwa, opowiedziały się za jej pozostawieniem ${ }^{94}$. Znamy liczne nadania $\mathrm{z}$ wergeldem $\mathrm{z}$ czasów księcia Albrechta (1525-1568) ${ }^{95}$. Główszczyznę jako prywatną opłatę za zabójstwo dopuszczały jeszcze rewizje prawa chełmińskiego z drugiej połowy XVI w. (lidzbar-

${ }^{89}$ Das alte Kulmische Recht, Buch III, XXXVIII b, c; Prawo starochetmińskie 1584 (1394), ks. III, art. 38a. Artykuł ten co prawda wykluczał matkę z grona beneficjentów na rzecz krewnego po mieczu, ale tylko w przypadku, gdy dziecko zmarło, zanim została wniesiona skarga za zabójstwo. Warto zauważyć, że prawo to jednak było przeróbką tzw. magdebursko-wrocławskiego systematycznego prawa ławniczego i trafiło do Prus dopiero u schyłku XIV w. Przy tym przywoływany artykuł został oparty na znanym skądinąd pouczeniu ławy magdeburskiej, por. Das alte Kulmische Recht, s. 63; E. Steffenhagen, op. cit., s. 201-204. Por. H. Brunner, op. cit., s. 13, który podaje przykłady dopuszczenia do podziału wergeldu tylko matek i córek (jako ewentualnych spadkobierczyń), pozostałe kobiety nie miały do tego prawa.

${ }^{90}$ Do Rzymu z pielgrzymką pokutną za zabójstwo miał się udać w 1452 r. karczmarz ze Świerczyn (kreczmer von Swirczschen), Księga ławnicza Starego Miasta Torunia, nr 1638.

91 G.A. von Mülverstedt, op. cit., s. 403-411; dla obszaru Niemiec por. P. Frauenstädt, op. cit., s. $127-132$.

${ }_{92}$ M. Bloch, op. cit., s. 151.

93 A. Pawiński, op. cit., s. 33-48.

${ }^{94}$ Acten der Ständetage Preussens unter der Herrschaft des Deutschen Ordens, hrsg. von M. Toeppen, Bd. II, Leipzig 1880, Bd. 2, s. 9, natychmiast za dotychczasowym prawem opowiedziało się rycerstwo, natomiast miasta poprosiły o czas do namysłu do następnego sejmiku. Brak informacji, aby się jednak temu sprzeciwiły. Sprawa wracała jeszcze pod obrady, por. ibidem, s. 579 (1443), ale nic się nie zmieniło.

95 G.A. von Mülverstedt, op. cit., s. 395. 
ska i nowomiejska) ${ }^{96}$. Natomiast w najpóźniejszej rewizji toruńskiej z 1594 r. została ona ograniczona tylko do przypadku zabójstwa nieumyślnego (jako „wyrównanie szkody”). Wynosiła wtedy 24 pruskie grzywny i była wypłacana powodowi w ciągu trzech miesięcy. Do każdej kary prywatnej dołączona była kara publiczna w postaci zapłaty w ciągu dwóch tygodni mulkty w wysokości 4 grzywien przypadającej sędziemu. Zabraniano zawierania jakiejkolwiek ugody poza sądem ${ }^{97}$. Wiadomo, że wergeld jako kara znika w landrechcie pruskim z 1620 r., stało się tak pod wpływem Caroliny i uznaniem tylko kar publicznych oraz wyrugowaniem z sądownictwa instytucji samopomocy i opłat kompozycyjnych. Jednocześnie też zakazano stosowania wróżdy pod groźbą kary śmierci ${ }^{98}$. Niemniej jednak w praktyce główszczyzna nadal była stosowana, ostatni przypadek opłaty wniesionej za zabójstwo znamy w Prusach z 1638 r. ${ }^{99}$, a w sąsiedniej Warmii nawet z 1658 r. ${ }^{100}$ Według ustaleń G.A. von Mülverstedta zamarła ostatecznie po 1650 r. w czasach rządów wielkiego elektora Fryderyka Wilhelma (zm. 1688). Dopiero odtąd zabójstwo w Prusach staje się wyłącznie przestępstwem publicznym ściganym z urzędu przez odpowiedni sąd.

Niniejsze opracowanie stanowi zaledwie wstęp do szerszego opracowania tematu. Już jednak przegląd literatury i części bazy źródłowej przyniósł pewne uporządkowanie tematyki, jak też nowe szczegółowe ustalenia bądź propozycje badawcze. Wstępnie nie wykluczono stosowania okupu w epoce Prus pogańskich. Zakon krzyżacki wprowadził zaś główszczyznę w postaci okupu pieniężnego (wergeldu), początkowo jednak godził się na zamienne jego stosowanie z wróżdą. Odrzucono opinię, że wergeld występował tylko w przywilejach dla wolnych pruskich, co prawda dominuje on w przywilejach wolnych Prusów, ale znajdują się też wzmianki dla wolnych pochodzenia litewskiego, polskiego i niemieckiego. Główszczyzna była powszechna i dotyczyła wszystkich wolnych warstw społecznych, nawet bez wzmianek o niej w nadaniach, a to ostatnie stanowiło swoiste wyróżnienie i przywilej. Stawki główszczyzny były zróżnicowane w zależności od pozycji społecznej

96 D. Janicka, op. cit., s. 96; Rewizja nowomiejska prawa chetmińskiego 1580 (1814) zwana także Jus Culmense emendatum lub Jus Culmense Polonicum, przekład I. Malinowska-Kwiatkowska, J. Sondel, zweryfikował Z. Rymaszewski, Toruń 1993, s. 58-59, art. XXXVII. 19.

97 W. Litewski, op. cit., s. 61; Ius Culmense ex ultima revisione, Danzig 1745, s. 271-272; D. Janicka, op. cit., s. 20-21, 55, 95-96.

98 W. Litewski, op. cit., s. 61, zakaz wróżdy, jak też sama jej zapowiedź pojawiły się już w rewizji toruńskiej prawa chełmińskiego, por. D. Janicka, op. cit., s. 91. Wydaje się zatem, że można odrzucić sugestię W.T. Paszuto, że krwawa zemsta w Prusach zanika już w XIV w., W.T. Paszuto, Pomezanija, s. 96.

99 G.A. von Mülverstedt, op. cit., s. 399-400; J.A. Lilienthal, Die Rechtspflege in der Altstadt Braunsberg von der ältesten Zeit bis zur preußischen Besitznahme im Jahre 1772, Der neuen Preußischen Provinzial-Blätter ander Folge, 1852, Bd. 1, s. 24, obaj za Ludwigiem von Baczko.

100 A. Szorc, op. cit., s. 407. 
danej osoby. Zamiast trzech wyróżniono cztery podstawowe stawki, dotychczas przyjmowane 16, 30 i 60 grzywien i dodatkową wynoszącą 8 grzywien. Uznano za przekonującą hipotezę, że wergeld wypłacano najbliższym krewnym zarówno w linii ojcowskiej, jak i macierzyńskiej. Z czasem prawa do jej części uzyskali władcy pruscy (Zakon, biskupi, kapituła). Obok opłaty pieniężnej wymagany był akt pokory, czyli rytuał kary honorowej. Główszczyzna stosowana była aż po połowę XVII w.

\section{Bibliografia}

\section{I. Źródła archiwalne}

1. Geheimes Staatsarchiv Preußischer Kulturbesitz, Berlin, XX. Hauptabteilung: Ordensbriefarchiv, Nr. 2434

2. Ostpreußische Folianten, Nr. 124, Nr. 332, Nr. 911a 29

\section{II. Źródła drukowane}

1. Acten der Ständetage Preussens unter der Herrschaft des Deutschen Ordens, hrsg. von M. Toeppen, Bd. II, Leipzig 1880, Bd. 2

2. Des allerdurchleuchtigsten großmechtigsten vnüberwindtlichsten Keyser Karls des fünfften: vnnd des heyligen Römischen Reichs peinlich gerichts ordnung auff den Reichsztägen zu Augspurgk vnd Regenspurgk inn jaren dreissig vnd zwey vnd dreisssig gehalten auffgericht vnd beschlossen, Mainz 1533

3. Das alte Kulmische Recht, mit einem Wörterbuche, hrsg. von C.K. Leman, Berlin 1838

4. Codex diplomaticus Warmiensis, hrsg. von C.P. Woelky, J.M. Saage, Bd. 2, Mainz 1864

5. Dusburgk Petrus de, Chronica terrae Prussiae, ed. J. Wenta et S. Wyszomirski, Monumenta Poloniae Historica. Nova series, t. 13, Kraków 2007 (polskie thumaczenie Piotr z Dusburga, Kronika ziemi pruskiej, przetłumaczył S. Wyszomirski, wstępem i komentarzem opatrzył J. Wenta, Toruń 2004)

6. Edictus Rothari, ed. F. Bluhme, Monumenta Germaniae Historica. Legum, Bd. IV, Hannoverae 1868

7. Die Ermahnung des Carthäusers, hrsg. von T. Hirsch, [w:] Scriptores rerum Prussicarum, Bd. 4, Leipzig 1870

8. Iura Prutenorum, wyd. J. Matuszewski, Toruń 1963

9. Ius Culmense ex ultima revisione, Danzig 1745

10. Die Kronike von Pruzinlant des Nicolaus von Jeroschin, hrsg. von E. Strehlke, [w:] Scriptores rerum Prussicarum, Bd. 1

11. Księga tawnicza Starego Miasta Torunia (1428-1456), wyd. K. Ciesielska, J. Tandecki, cz. 1-2, Toruń 1992-1993

12. Leges Saxonum, ed. K. von Richthofen, K.F. von Richthofen, Monumenta Germaniae Historica. Legum, Bd. V, Hannover 1875 
13. Lex Salica, hrsg. von J.K.A. Eckhardt, Monumenta Germaniae Historica. Legum Sectio I. Legum nationum Germanicarum, T. IV, Pars II, Hannoverae 1969

14. Najstarszy zwód prawa polskiego, wyd. J. Matuszewski i J. Matuszewski, Łódź 1995

15. Prawda Russkaja, wyd. B.D. Grekow, t. 2, Moskwa-Leningrad 1947

16. Prawo starochetmińskie 1584 (1394), red. W. Maisel, Z. Zdrójkowski, przekład A. Bzdęga, A. Gaca, Toruń 1983

17. Preußisches Urkundenbuch, Bd. 1, 2, hrsg. von A. Seraphim, Königsberg 1909; Bd. 2, 2, hg. von M. Hein, E. Maschke, Königsberg 1939; PU, Bd. 3, 1, hg. von M. Hein, Königsberg 1944; Bd. 5, 2, hrsg. von K. Conrad, Marburg 1973

18. Rewizja nowomiejska prawa chetmińskiego 1580 (1814) zwana także Jus Culmense emendatum lub Jus Culmense Polonicum, przekład I. Malinowska-Kwiatkowska, J. Sondel, zweryfikował Z. Rymaszewski, Toruń 1993

19. Tacitus P. Cornelius, Germania, przekład T. Płóciennik, wstęp i komentarz J. Kolendo, Poznań 2008

\section{Literatura}

1. Białuński G., Bevölkerung und Siedlung im ordensstaatlichen und herzoglichen Preussen im Gebiet der ,, Grossen Wildnis” bis 1568, Hamburg 2009

2. Białuński G., Osadnictwo regionu Wielkich Jezior Mazurskich od XIV do początków XVIII wieku. Starostwa leckie (giżyckie) i ryńskie, Olsztyn 1996

3. Bloch M., Spoleczeństwo feudalne, Warszawa 2002

4. Brunner H., Sippe und Wergeld in den niederdeutschen Rechten, „Zeitschrift der Savigny-Stiftung. Germanistische Abtheilung", 1882, Bd. 3

5. Ciszewski S., Wróżda i pojednanie, Warszawa 1900

6. Długokęcki W., Instytucja wodzostwa u Prusów w XIII wieku, [w:] Instytucja „wczesnego państwa” w perspektywie wielości i różnorodności kultur, red. J. Banaszkiewicz, M. Kara, H. Mamzer, Poznań 2013

7. Długokęcki W., Uwagi o genezie i rozwoju wczesnośredniowiecznych Prus do początków XIII wieku, „Pruthenia” 2 (2006)

8. Dobrosielska A., Białuński G., Dyskretny urok źródet czyli o aktualności pracy Maxa Toeppena , Exkurs über die Verschreibungen des Ordens für Stammprußen im 13. Jahrhundert”, „Pruthenia” 8 (2013)

9. Dygo M., ,Hospites eciam eo iure fruantur, quo et milites Mazouienses”. W sprawie lokacji Płocka w 1237 roku, „Kwartalnik Historyczny” 1993, nr 3

10. Estreicher S., Oźródłach najdawniejszego prawa chetmińskiego. [Nieznany zwód mazowiecki będacy kompilacją najstarszych ortyli chetmińskich z XIII i XIV wieku], [w:] Studia Culmensia historico-iuridica, t. 1

11. Frauenstädt P., Blutrache und Todtschlagsühne im deutschen Mittelalter. Studien zur Deutschen Kultur- und Rechtsgeschichte, Leipzig 1881

12. Germerhausen P., Siedlungsentwicklung der preussischen Ämter Holland, Liebstadt und Mohrungen vom 13. bis 17. Jahrhundert, Marburg/Lahn 1970

13. Gudlat E., Kehlen. Geschichte und Entwicklung, Rotenburg 1973

14. Janicka D., Prawo karne w trzech rewizjach prawa chetmińskiego z XVI wieku, Toruń 1992 
15. Kamińska K., Prawo chetmińskie $w$ świetle najstarszych ksiag miejskich Chetmna i Torunia (XIV i XV w.) [w:] Studia Culmensia historico-juridica czyli księga pamiatkowa 750-lecia prawa chetmińskiego, t. 1, red. Z. Zdrójkowski, Toruń 1990

16. Kętrzyński W., O ludności polskiej w Prusiech niegdyś krzyżackich, Lwów 1882

17. Klementowski M., Powszechna historia ustroju, Warszawa 2012

18. Koranyi K., Powszechna historia prawa, Warszawa 1976

19. Kurczewski J., Prawo prymitywne: zjawiska prawne $w$ społeczeństwach przedpaństwowych, Warszawa 1973

20. Lilienthal J.A., Die Rechtspflege in der Altstadt Braunsberg von der ältesten Zeit bis zur preußischen Besitznahme im Jahre 1772, „Der neuen Preußischen Provinzial-Blätter ander Folge" 1 (1852)

21. Litewski W., Landrecht des Herzogtums Preussen von 1620. I. Strafrecht, Warszawa-Kraków 1982

22. Łowmiański H., Prusy pogańskie, [w:] idem, Prusy - Litwa - Krzyżacy, Warszawa 1989 (pierwsze wyd. Toruń 1935)

23. Łowmiański H., Studia nad początkami społeczeństwa i państwa litewskiego, t. 1, Wilno 1931

24. Matern G., Um Hals und Hand. Beiträge zur Geschichte der Rechtspflege im Ermland, Braunsberg 1912

25. Matuszewski J., Główszczyzna chłopska i szlachecka, „Kwartalnik Historyczny” 1964, nr 1

26. Modzelewski K., Barbarzyńska Europa, Warszawa 2004

27. Modzelewski K., Legem ipsam vetare non possumus. Królewski kodyfikator wobec potęgi zwyczaju, [w:] Historia, idee, polityka (księga dedykowana J. Baszkiewiczowi), Warszawa 1995

28. Modzelewski K., Zemsta, okup i podmiot moralny w prawach barbarzyńskich, [w:] Aetas media, aetas moderna. Studia ofiarowane prof. H. Samsonowiczowi, red. H. Manikowska, A. Bartoszewicz, W. Fałkowski, Warszawa 2000

29. Mülverstedt G.A. von, Beiträge zur Geschichte des Wergeldes in Preussen, „Der neuen Preussischen Provinzial-Blätter andere Folge" 3-4 (1853)

30. Okulicz-Kozaryn Ł., Dzieje Prusów, Wrocław 1997

31. Paszuto W.T., Pomezanija. „Pomiezanskaja Prawda” kak istoriczeskij istocznik izuczenija obszczestwiennogo i politiczeskogo stroja Pomiezanii XIII-XIV ww., Moskwa 1955

32. Pawiński A., O pojednaniu w zabójstwie wedtug prawa polskiego, Warszawa 1884.

33. Roth A., Wergeld, [w:] Lexicon des Mittelalters, Teil 8, München 1997

34. Saborowski E., Besiedlung und Nationalitätenverhältnisse des Hauptamtes Ortelsburg (zur Zeit der Herrschaft des Deutschordens), Mitteilungen der Literarischen Geselschaft Masovia, 1925, H. 30

35. Sikorski D.A., Instytucje władzy u Prusów w średniowieczu (na tle struktury spotecznej i terytorialnej), Olsztyn 2010

36. Steffenhagen E., Deutsche Rechtsquellen in Preussen vom XIII. bis zum XVI. Jahrhundert, Leipzig 1875 
37. Suchocki J., Mitologia battyjska, Warszawa 1991

38. Szacherska S.M., Próba walki o główszczyznę mieszczańska w XVw. [w:] „Cultus et cognito”. Studia z dziejów średniowiecznej kultury, red. S.K. Kuczyński $\mathrm{i}$ in., Warszawa 1976

39. Szorc A., Dominium warmińskie 1243-1772. Przywilej i prawo chetmińskie na tle ustroju Warmii, Olsztyn 1990

40. Toeppen M., Exkurs über die Verschreibungen des Ordens für Stammprußen im 13. Jahrhundert, [w:] Scriptores rerum Prussicarum, hrsg. von T. Hirsch, M. Toeppen, E. Strehlke, Bd. 1, Leipzig 1861

41. Toeppen M., Geschichte Masurens, Danzig 1870 (w polskim tłumaczeniu, idem, Historia Mazur, Olsztyn 1995)

42. Vercamer G., Siedlungs-, Sozial- und Verwaltungsgeschichte der Komturei Königsberg in Preußen (13.-16. Jahrhundert), Marburg 2010

43. Voigt J., Geschichte der Eidechsengesellschaft in Preussen, Königsberg 1823

44. Voigt J., Geschichte Preussens, von den ältesten Zeiten bis zum Untergang der Herrschaft des Deutschen Ordens, Bd. 4, Königsberg 1830

45. Weber L., Preussen vor 500 Jahren in culturhistorischer, statistischer und militarischer Beziehung, nebst Special-Geographie, Danzig 1878

46. Wenskus R., Über einige Probleme der Sozialordnung der Prußen, w: idem, Ausgewählte Aufsätze zum frühen und preußischen Mittelalter. Festgabe zu seinem siebzigsten Geburtstag, Sigmaringen 1986

\section{REVENGE AS A MOTHER OF JUSTICE. WEREGELD IN THE STATE OF THE TEUTONIC ORDER AND THE DUCHY OF PRUSSIA}

\section{Summary}

This article attempts to summarize the issue of the application of wergeld on Prussian lands. It represents a scoping project with an aim to aid a broader development of the subject. The very review of the literature review and source material already offers a certain systemic approach as well as detailed findings and proposals for research. First of all, it has been found that the introduction of wergeld did not exclude the use of ransom in the era of pagan Prussia. Under the Teutonic Order weregeld had the form of ransom money and was an alternative to a feoff. Although weregeld applied predominantly to free Prussians, references to its use among the Lithuanians, Poles and Germans can also be found. Weregeld was widespread among all free social strata. Its rates varied depending on the social status of a person. What has also been established is that instead of the three previously distinguished rates 16, 30 and 60 fines, there was also a fourth basic rate of 8 . Another convincing hypothesis is that 
wergeld was paid to the next of kin, both paternal and maternal. Overtime a practice developed whereby part of the weregeld was paid to the Prussian rulers (i.e. to the Teutonic Order, the bishops, and Cathedral chapters). In addition to the monetary payment, an act of humility was required, which was the ritual punishment of honor. Weregeld was used up to the mid-seventeenth century.

\section{LA VENGEANCE EST LA MEILLEURE JUSTICE. LE WERGILD DANS LA PRUSSE TEUTONIQUE ET LE DUCHÉ DE PRUSSE}

\section{Résumé}

Les auteurs de l'article ont essayé de résumer le problème d'application de le wergild sur les terres prussiennes. Il constitue à peine une reconnaissance de recherche dont l'objectif constitue l'élaboration de ce sujet dans un contexte plus large. Néanmoins, la revue de la littérature et d'une partie de la base de données sources ont déjà permis de systématiser la thématique d'une certaine manière, ainsi que de nouveaux faits détaillés, soit les propositions de recherche. Dans un premier temps, l'utilisation de la rançon à l'époque de la Prusse païenne n'a pas été exclue, pendant que l'Ordre Teutonique a mis en place le wergild sous forme d'une rançon pécuniaire (wergild), pourtant il acceptait initialement l'application de la poena capitis de manière interchangeable avec la vendetta. L'opinion que le wergild n'était présent que dans les privilèges de l'État libre de Prusse a été rejetée, il est vrai que le wergild est dominant dans les privilèges de l'État libre de Prusse, mais il y a en même temps des mentions concernant les nations libres ayant des origines de la nation lithuanienne, polonaise et allemande. Le wergild était universelle et concernait toutes les couches sociales libres. Les montants de wergild étaient différenciés en fonction de la position sociale d'une personne donnée. Il faut distinguer quatre montants principaux, au lieu de trois, qui étaient adoptés à cette époque-là : 16,30 et 60 amendes et un montant supplémentaire égal à 8 amendes. L'hypothèse que le wergild était payé aux parents les plus proches, tant dans la lignée parentale que maternelle, a été jugée convaincante. Les droits à sa partie ont été acquis dans le temps par les souverains prusses (Ordre, évêques, chapitre). À côté de la peine pécuniaire, l'acte d'humilité était indispensable, à savoir le rituel des châtiments d'honneur. Le wergild était appliquée jusqu'à la moitié du XVII siècle. 
